\title{
IMPACT OF FAILURE OF A CENTRAL SECURITIES DEPOSITORY \\ PARTICIPANT ON FINALITY AND IRREVOCABILITY OF SETTLEMENT OF SECURITIES
}

Vivienne A Lawack-Davids

BJuris LLB LLM LLD

Professor, Executive Dean of Law

Nelson Mandela Metropolitan University

Port Elizabeth

Lindi Coetzee

BJuris LLB LLM

Senior Lecturer

Nelson Mandela Metropolitan University

Port Elizabeth

\section{SUMMARY}

In view of the current global meltdown and the recession in South Africa, the question arises whether the legal framework pertaining to finality of settlement of securities is sufficiently robust to cope with failure of a central securities participant. This article examines this question and highlights some of the problems that exist with regard to uncompleted contracts in the Strate (Share Transactions Totally Electronic) environment. The authors conclude with certain recommendations to overcome the identified problems.

\section{1}

\section{INTRODUCTION}

In the event of insolvency or liquidation on the ground that the company is unable to pay its debts the general common law rule is that the trustee or liquidator has the election to decide whether to abide by uncompleted contracts or whether to repudiate such agreements. The Insolvency Act ${ }^{1}$ provides for certain exceptions to the general discretion of the trustee. Section $35 \mathrm{~A}$ of the Insolvency Act that deals with transactions on an

24 of 1936 (hereinafter "the Insolvency Act"). 
exchange is one such exception where the trustee's (liquidator's) election has been taken.

In terms of the Securities Services Act $^{2}$ Strate Limited ${ }^{3}$ is the authorised central securities depository (CSD) for the electronic settlement of securities in South Africa. At present Strate handles the settlement of equities, warrants and bonds for the JSE Limited and Bond Exchange of South Africa. It is an unlisted public company with dematerialised assets under custody in excess of 5 million ZAR (rands).

In view of the current turbulent global financial situation, the question arises as to whether the legal framework pertaining to finality of settlement of securities is sufficiently robust to cope with failure of a CSD Participant. A CSD Participant refers to a person that holds in custody and administers securities or an interest in securities and has been accepted in terms of section 34 of the SSA by a CSD as a participant in that CSD. ${ }^{5}$

This purpose of this article is to assess the impact of failure of a CSD Participant on finality and irrevocability of settlement of securities. To this end, this article describes the current legal framework and highlights problems with regard to uncompleted contracts in the current legal framework. The article includes a discussion of the applicable provisions of the Companies Act. ${ }^{6}$ The issue of netting falls outside the ambit of this article and will be discussed in a separate article. The article concludes with a number of recommendations on how to rectify the identified problems.

\section{STRATE, THE CSD}

In 1999 the JSE Limited, ${ }^{7}$ in collaboration with South Africa's four largest commercial banks, established their own central securities depository (CSD) known as STRATE (Share Transactions Totally Electronic). The function of Strate was the settlement and custody of all the shares traded on the JSE. During this time the Bond Exchange of South Africa (BESA) operated a separate settlement vehicle and CSD, known as UNEXCor (Universal Exchange Corporation). In August 2003 Strate Limited was formed through the merger of Strate, UNEXCor and Central Depository Limited. Strate handles the settlements of equities, warrants and bonds for the JSE Limited and BESA. ${ }^{8}$ BESA has recently been consolidated into the JSE. ${ }^{9}$

Act 36 of 2004 (hereinafter "the SSA").

Strate was formerly an acronym for Share Transactions Totally Electronic (STRATE). The company's corporate identity has since been changed to Strate in title case.

4 For more detail, see http://www.strate.co.za (accessed 2009-07-08).

5 See the definition in S 1 of the SSA. See also the functions of a participant in s 35 of the SSA (hereinafter "Participant" or "CSD Participant" used interchangeably).

671 of 2008 (hereinafter "the 2008 Companies Act").

7 JSE Limited (hereinafter "the JSE").

8 See Van Zyl, Botha, Skerrit and Goodspeed Understanding South African Financial Markets 3ed (2009) 217.

9 On 27 October 2008 the JSE announced that it had made a conditional offer to acquire the entire ordinary share capital of BESA. On 6 February 2009 the requisite majority of the BESA shareholders approved the proposed consolidation. This was followed by the 
The SSA, in particular Chapter IV of the SSA, deals with custody and administration of securities. A central securities depository is defined as a person licensed as a central securities depository under section 32 of the SSA.

The CSD makes depository Rules (CSD Rules) in accordance with the provisions of the SSA. ${ }^{10}$ In terms of section 33 of the SSA, a CSD:

- must enforce the depository rules (CSD Rules), may amend or suspend the CSD Rules;

- must supervise compliance by participants with the Act and the CSD Rules; and

- may issue directives. ${ }^{11}$

Section 39 of the SSA provides the framework in terms of which the CSD may issue Rules. In turn, the Rules provide the framework in terms of which the CSD may issue Directives. The order of precedence of legislation is, therefore, the SSA, CSD Rules and Directives. The Rules are binding on the CSD, CSD Participants, issuers and clients. ${ }^{12} \mathrm{~A}$ participant is defined in the SSA as a person that holds in custody and administers securities or an interest in securities and that has been accepted in terms of section 34 by a CSD as a participant in that CSD. ${ }^{13}$ At present there are seven CSD Participants in Strate, six are Bank Participants, and Computershare Limited is the only Non-Bank Participant. ${ }^{14}$

Strate issued CSD Rules and Directives in accordance with its licence granted by the Financial Services Board and in accordance with the provisions of the SSA. ${ }^{15}$

\section{FINALITY AND IRREVOCABILITY OF SETTLEMENT}

\section{General}

Revocation is one of a number of possible threats to finality. ${ }^{16}$ It is in the interest of transferees and transferee banks for funds or securities transfer

unconditional approval from the Competition Tribunal on 3 June 2009. On 9 June 2009 the High Court of South Africa sanctioned the consolidation and on 22 June 2009 BESA became a wholly owned subsidiary of the JSE Ltd. See JSE website http://www.jse.co.za and BESA website http://www.bondexchange.co.za (accessed 2009-07-08).

10 See definition of depository rules in S 1 of the SSA.

11 See s 33(a)-(d) of the SSA. These are the functions of the CSD pertaining to Rules and Directives, but are no the only functions of the CSD. The other functions are set out in $S$ $33(\mathrm{e})$-(0) of the SSA.

12 See S 39(4) of the SSA read with s 1 of the SSA. A "client" means a person who uses the services of an authorised user or a participant, as the case may be. An "issuer" refers to an issuer of securities, including for purposes of Chapter IV of the SSA, money market securities.

13 See $s$ of the SSA.

14 These are, ABSA Bank Ltd, Computershare Ltd, First National Bank Ltd, Nedbank Ltd, the Standard Bank of South Africa Ltd and Societé Géneral.

15 The CSD Rules are issued following the procedure laid down in s 61 of the SSA and Rule 2 determines how Directives are issued. 
instructions to be irrevocable as early in the transfer process as possible. However, on occasion transferors may wish to revoke funds or securities transfer instructions they have issued, because of problems associated with the underlying transaction or because of the intervening insolvency of the transferee.

The words "final settlement" can be defined as "the discharge of an obligation by a transfer of funds and a transfer of securities that have become irrevocable and unconditional". In general, therefore, when a funds or securities "transfer" is said to be "final", it is usually understood to mean that the transferor's funds or securities account is reduced and the funds or securities transfer can no longer be set aside or reversed. ${ }^{17}$

\section{Finality and irrevocability of settlements in Strate}

\section{1 "Commitment"}

The transfer of securities which takes place on settlement is a transfer of legal title in terms of the Companies Act (the appropriate legal manner for ownership or interest in securities to be vested). The term "securities" is not defined in the Companies Act ${ }^{18}$ but a definition of the term has been included in the Companies Act 71 of 2008. The definition of the term as provided for in the SSA is adopted in the 2008 Companies Act.

The SSA defines securities as:

"shares, stocks and depository receipts in public companies and other equivalent equities, other than shares in a share block company as defined in the Share Blocks Control Act, 1980 (Act No. 59 of 1980); notes; derivative instruments; bonds; debentures; participatory interests in a collective investment scheme as defined in the Collective Investment Schemes Control Act, 2002 (Act No. 45 of 2002), and units or any other form of participation in a foreign collective investment scheme approved by the Registrar of Collective Investment Schemes; units or any other form of participation in a collective investment scheme licensed or registered in a foreign country; instruments based on an index; the securities that are listed on an external exchange; and an instrument declared by the registrar by notice in the Gazette to be a security for the purposes of the Companies Act and rights in the securities. The term 'securities' excludes money market instruments ${ }^{19}$ and any security specified by the registrar by notice in the Government Gazette."

The settlement rules create reciprocal obligations to settle. Rolling settlement is used. In Strate, "finality" occurs on the irrevocable "commitment" of the CSD Participant to settle orders to SAFIRES ${ }^{20}$ at a

16 The Barings collapse illustrated the effect where a payment system allows for the reversal of payments if something goes wrong which may have had nothing to do with the transferor.

17 See the Bank for International Settlements A Glossary of Terms Used in Payments and Settlement Systems March 200325.

1861 of 1973 (hereinafter "the 1973 Companies Act").

19 Except for the purposes of Chapter IV.

20 SAFIRES means the Southern African Financial Instruments Real Time Electronic Settlement System, the clearing, settlement and depository system of the CSD. 
particular time on day three after the trading day, ${ }^{21}$ based on the matched instructions received. During commitment on $\mathrm{T}+3{ }^{22}$ the CSD Participants are automatically committed to the transaction and guarantee the payment (cash) or "delivery" (scrip).

"Commitment" is a specific action taken by CSD Participants acting on behalf of their clients in the settlement procedure. The objective of the confirmation of settlement order is to allow the CSD Participants to commit their intention to settle to Strate.

The procedure commences with the generation and reservation in parallel of the delivery instruction for the payment leg and securities leg. Following this reservation, the settlement of the payment leg can be completed, resulting in a settlement-confirmation message. Upon receipt of the settlement-confirmation message, transfer of ownership will be affected as provided for in the Companies Act.

The "commitment" as prescribed in the settlement procedure is contractually binding and legally enforceable against the relevant CSD Participants of the settlement system and would be binding on the CSD, CSD Participants, issuers and clients to whom the Rules are applicable. ${ }^{24}$ In terms of the irrevocable commitment, CSD Participants (inter partes) are obliged to settle as prescribed.

\section{2 "DvP"}

The Companies Act is specifically relevant in the context of Strate in the instance of finality and irrevocability of settlement and arrangements for achieving Delivery-versus-Payment (DvP). DvP is a multi-staged process in Strate. The process is structured to:

- receive obligations for settlement;

- match instructions;

- irrevocably confirm and commit to settlement; and

- settle on $T+5$, in the case of equities and $T+3$ in the case of bonds.

Eliminating legal threats to finality of settlement substantially increases certainty, especially in the areas of fraud and insolvency. Section $91 \mathrm{~A}$ of the 1973 Companies Act and, similarly, section 53 of the 2008 Companies Act provide for the transfer of uncertificated securities. ${ }^{25}$ At present the prima

21 Hereinafter " $\mathrm{T}+3$ ".

22 Strate settlement Directives, Commitment of settlement orders should take place in SAFIRES by $12 \mathrm{~h} 00$ on $\mathrm{T}+3$ according to Directive SCC - Operational Windows paragraph 3.3 for on-exchange transactions. Off-market instructions will be committed by the CSD Participants by no later than $17 \mathrm{~h} 00$ on $\mathrm{T}+3$. See par 3.3.2.5 and par 4.7 of Directive SCV Best Practices for Off-market Trades On-exchange transactions are those transactions occurring on an exchange, as opposed to "off-market" transactions which do not occur on an exchange, but are nevertheless settled in Strate.

$23 \mathrm{~S} 91 \mathrm{~A}$ of the 1973 Companies Act and s 53 of the 2008 Companies Act. The former is still in operation till 2010 when the new Companies Act comes into effect. This is dealt with at par 3 22 below.

24 S 39(4) of the SSA.

25 S 53 provides: 
facie transfer of ownership takes place at sub-register level. ${ }^{26}$ This is achieved when the corresponding debits and credits are effected; that is, upon the delivery of securities versus the payment of funds. This concept is referred to as Delivery versus Payment ("DVP") on day five after trading day. ${ }^{27}$ The general rule is that irrevocable finality of payment follows settlement finality of the payment instruction.

Rule 6.7.2 states that a participant must, upon receipt of an Authenticated Instruction from the CSD advising it of the completion of a transaction which affects the balance of a Securities Account held by the participant, complete a corresponding Entry in the relevant Securities Account in accordance with

"(1) The transfer of uncertificated securities in an uncertificated securities register may be effected only -

(a) by a participant or central securities depository;

(b) on receipt of -

(i) an instruction to transfer sent and properly authenticated in terms of the rules of a central securities depository; or

(ii) an order of a court; and

(c) in accordance with this section and the rules of the central securities depository.

(2) Transfer of ownership in any uncertificated securities must be effected by -

(a) debiting the account in the uncertificated securities register from which the transfer is effected; and

(b) crediting the account in the uncertificated securities register to which the transfer is effected, in accordance with the rules of a central securities depository.

(3) The requirements of section 51(5), read with the changes required by the context, apply with respect to a transfer of uncertificated securities.

(4) A transfer of ownership in accordance with this section occurs despite any fraud, illegality or insolvency that may -

(a) affect the relevant uncertificated securities; or

(b) have resulted in the transfer being effected, but a transferee who was a party to or had knowledge of the fraud or illegality, or had knowledge of the insolvency, as the case may be, may not rely on this subsection.

(5) A court may not order the name of a transferee contemplated in this section to be removed from a uncertificated securities register, unless that person was a party to or had knowledge of a fraud or illegality as contemplated in subsection (4).

(6) Nothing in this section prejudices any power of a participant or central securities depository, as the case may be, to effect a transfer to a person to whom the right to any uncertificated securities of a company has been transmitted by operation of law."

26 In terms of $\mathrm{S} 91 \mathrm{~A}$ of the Companies Act, Strate has implemented a model in which the legally registered record of holding balances for a Strate-approved security may be recorded on a:

- CSD Participant subregister in name of a nominee; or

- CSD Participant subregister in own name of client or investor.

As a result of the chosen model, a transfer in the Strate environment constitutes a transfer of legal title, rather than a transfer of beneficial interests within the registered holding of one nominee or trustee. Section $91 \mathrm{~A}(4)(\mathrm{a})$ of the Companies Act provides as follows:

"Transfer of ownership in an uncertificated security shall be effected upon the debiting and crediting, respectively, of both the account in the subregister from which the transfer is effected and the account in the subregister to which transfer is to be made, in accordance with the rules of the central securities depository." The subregister forms part of the relevant company's register of members for the purposes of the Companies Act. In terms of the Companies Act, the holding balances maintained by the CSD Participants are the record of legal title. Holdings on the CSD Participants' subregisters are recognised in law as if they were maintained directly by the issuer."

27 Hereinafter " $T+5$ ". 
the Client Mandate, the Rules, Directives, section 91A of the Companies Act, ${ }^{28}$ where applicable, the Act and other relevant legislation. Any beneficial holding at lower tiers must likewise be recorded. ${ }^{29}$ Whereas section $91 \mathrm{~A}$ refers to transfer of ownership which occurs at the sub-register, section 53(4) refers to transfer of ownership occurring through the debiting and crediting of the account in the uncertificated securities register to which the transfer is effected, in accordance with the rules of a central securities depository (authors' own emphasis). Section 1 of the 2008 Companies Act defines "uncertificated securities register" as the record of uncertificated securities administered and maintained by a participant or central securities depository, as determined in accordance with the rules of a central securities depository, and which forms part of the relevant company's securities register established and maintained in terms of Part E of Chapter 2. The broader term has been inserted to pave the way should it become necessary to implement a different or alternative model of securities settlement.

Unlike section $91 \mathrm{~A}$, reference to insolvency has been included in section 53(4) which states that a transfer of ownership in accordance with section 53 occurs despite any fraud, illegality or insolvency that may -

(a) affect the relevant uncertificated securities; or

(b) have resulted in the transfer being effected, but a transferee who was a party to or had knowledge of the fraud or illegality, or had knowledge of the insolvency, as the case may be, may not rely on subsection (4).

The protection normally afforded to a bona fide purchaser has been extended to include insolvency. The effect of the inclusion of the words "or insolvency" is that settlement remains final despite insolvency.

\section{PARTICIPANT FAILURE AND FINALITY}

For the purposes of this article, failure of a participant occurs when such participant is placed under curatorship or under judicial management or under business rescue or is liquidated on the ground that it is unable to pay its debts or where the participant makes a compromise or arrangement with its creditors. ${ }^{30}$ If a participant so fails, the Controlling Body of the CSD may terminate the participation of the participant by terminating the licence of such failed participant. ${ }^{31}$ In the event of insolvency of a participant or client, there are other stakeholders apart from the CSD which are involved. These include the liquidator, curator, business rescue practitioner or judicial manager, creditors and debtors of the participant or client. The consequences of liquidation, curatorship and judicial management in the context of the Strate environment are discussed below:

\footnotetext{
S 53 of the 2008 Companies Act.

Eg, sub-sub-register and sub-sub-sub-register level.

See Part E Compromise with Creditors of the 2008 Companies Act.

31 See Rule 3.10.1.1. The "Controlling Body" refers to the Board of the CSD in terms of $s 1$ of the CSD Rules.
} 


\section{Effect of liquidation of participant}

The existence of a company as a separate legal entity is terminated by dissolution of the company. The process of dealing with or administering a company's affairs prior to dissolution by ascertaining and realising its assets and first applying them in the payment of creditors of the company according to their order and preference and then distributing the residue (if any) among the shareholders of the company in accordance with their rights, is known as winding-up or liquidation of the company.

The 2008 Companies Act provides that Chapter 14 of the 1973 Companies Act will continue to apply with respect to the winding-up and liquidation of companies under the new Act as if the 1973 Companies Act has not been repealed. ${ }^{32}$ Section 339 of the 1973 Companies Act provides that the provisions of the law of insolvency apply mutatis mutandis to any matter not specifically provided for by the Companies Act. The 1973 Companies Act further contains a number of specific provisions that provide for the application of the law of insolvency. ${ }^{33}$

Once the winding-up of a company has commenced it is important that it be brought to the attention of certain officials and the public. A copy of the provisional and final winding-up order and any order of court staying, amending or setting such order aside, must be sent immediately to the registrar of the court. ${ }^{34}$ After receipt of the winding-up order, the Master must give notice of the winding-up in the Government Gazette. ${ }^{35}$ If the participant is listed on the JSE, ${ }^{36}$ the JSE must be notified in writing of the liquidation of the participant. The JSE must also be informed in writing of the date upon which the liquidated company's register of members will close. ${ }^{37}$ The commencement of winding-up proceedings has the effect of freezing the share ledger account of every member. ${ }^{38}$ Any alteration of the status of a member after the commencement of the winding up order without the permission of the liquidator will be null and void. ${ }^{39}$ Similarly every disposition of property, including rights of action by the company being wound up and unable to pay its debts made after the commencement of the winding-up, will be void unless a court orders otherwise. ${ }^{40}$ Where the court has made an order for the winding-up of a company (that is, the participant) all civil proceedings by or against the company is suspended until the appointment

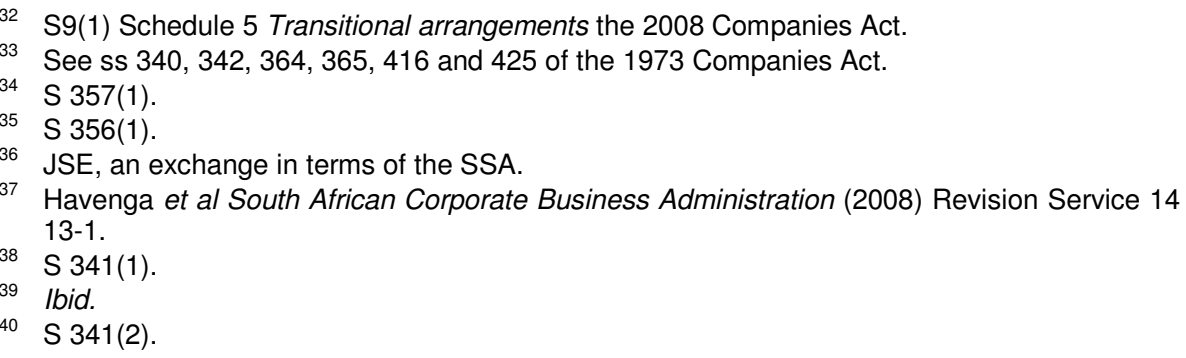


of a liquidator ${ }^{41}$ and any attachment or execution of assets of the company after the commencement of the winding-up is void. ${ }^{42}$

When the participant is compulsorily wound up by the court, the control of the company's affairs is taken from the directors and is vested in the Master of the High Court until the liquidator is appointed. The Master of the High Court appoints the liquidator ${ }^{43}$ and the latter is accountable to the Master for the proper performance of his/her duties. The liquidator is not accountable to the directors of the company. In van Zyl NO v CIR ${ }^{44}$ the court held that the assets of the company remain vested in the company during its liquidation and that the directors are replaced with the liquidator as manager of the company. ${ }^{45}$ In AMS Marketing Co (Pty) Ltd v Holzman ${ }^{46}$ the court said that it was "of the opinion that the liquidator enjoys dual capacity. In one sense he is a primary organ of the company in whom the powers formerly residing in the directors are vested. In the other his position is similar to that of a trustee of an insolvent estate, having the power to recover assets, realise them and distribute the proceeds to the person entitled thereto".

In terms of section 391 of the Companies Act the liquidator must wind up the affairs of the company, determine the claims of the creditors, pay the liquidation costs and settle the claims of creditors. The 1973 Companies Act provides the liquidator with wide powers to enable him to fulfil his duties, for example, to bring or defend legal proceedings, to compromise or admit claims, to enter into an arrangement, to submit disputes to arbitration, to carry on or discontinue the business of the company, to sell movable or immovable property and to abide by or terminate any agreements entered into prior to liquidation. ${ }^{47}$ The Act also places numerous duties upon the liquidator. ${ }^{48}$ The liquidator occupies a fiduciary position in relation to the company which is similar to the fiduciary position of directors.

Upon the granting of the liquidation order a concursus creditorum is established which is aimed at ensuring that the company's property is collected and distributed among creditors in the prescribed order of preference. ${ }^{49}$ No creditor may thereafter do anything to alter the rights of other creditors and no set-off may take place unless mutuality of respective claims existed at the time of the winding-up. ${ }^{50}$

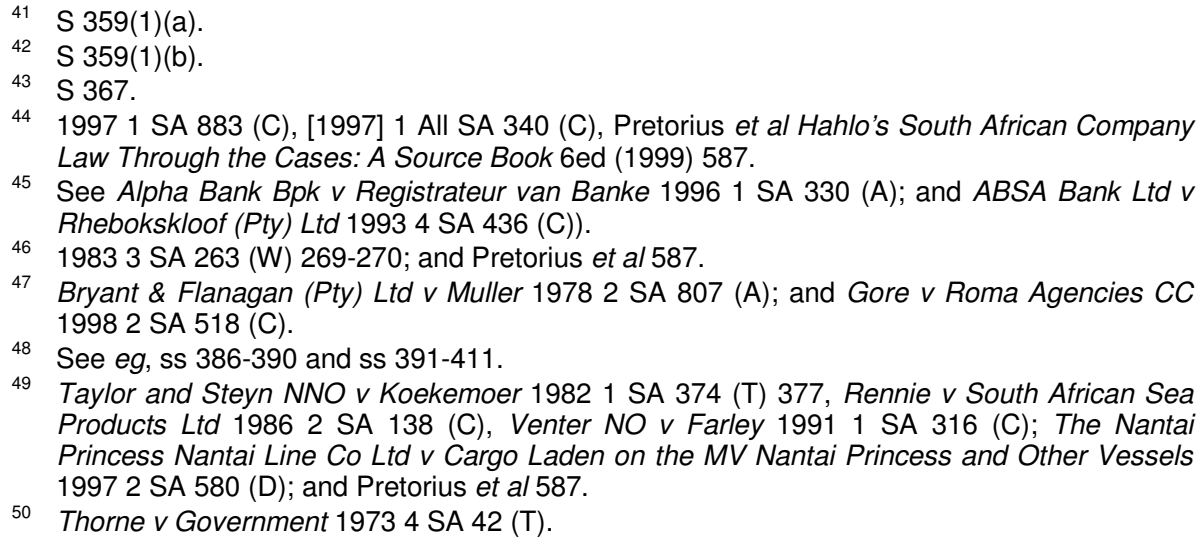

49 Taylor and Steyn NNO v Koekemoer 19821 SA 374 (T) 377, Rennie v South African Sea Products Ltd 19862 SA 138 (C), Venter NO v Farley 19911 SA 316 (C); The Nantai Princess Nantai Line Co Ltd $v$ Cargo Laden on the MV Nantai Princess and Other Vessels 19972 SA 580 (D); and Pretorius et al 587.

50 Thorne $v$ Government 19734 SA 42 (T). 
The effect of a liquidation of a Non-bank Participant in accordance with the Companies Act and the Insolvency Act is that the directors are divested of control of the company. The assets of the company are placed under the control of the liquidator and the company may not continue conducting its business, other than may be necessary for its beneficial winding-up. Where the liquidator upon his or her appointment continues the carrying on of the business of the company, such business is no longer carried on for the benefit of the members of the company but rather for the benefit of distributing the company's assets among its creditors. ${ }^{51}$ At this stage the Non-bank Participant's Strate licence may be terminated.

In respect of a Bank Participant, the function of the liquidator is to take possession of all movable and immovable assets of the bank, to realise such property and to apply the proceeds of the realisation to the payment of the costs of liquidation and the claims of the creditors. ${ }^{52}$ All cash with the bank would form part of the pool of assets of the bank and any depositors would have a claim against the bank in relation to any cash held with the bank, which claim would have to be proved in the ordinary course of events. The Participant's Strate licence may be terminated.

It is evident from paragraph 322 above that transfer of ownership (DvP) is affected notwithstanding any fraud, illegality or insolvency. ${ }^{53}$ The Companies Act protects the bona fide purchaser rather than the victim of theft, or fraud on DvP. ${ }^{54}$ The result is that despite any claim of fraud or other illegality, final irrevocable DvP is accomplished in Strate. Even though section 53 of the 2008 Companies Act now refers to insolvency, the SSA does not address the question of "finality" in the case of insolvency of a CSD Participant.

The question arises whether there is final and irrevocable settlement upon commitment if a liquidator is appointed to a CSD Participant during the settlement process after "final commitment", but on or before settlement day.

When CSD Participants have "committed" to the securities transaction, they have contractually signified their irrevocable commitment and the CSD Participants (inter partes) are obliged to settle as prescribed. It can be argued that if a CSD Participant or client in the settlement system goes insolvent during the settlement process after "final commitment", but on or before settlement day, there is no final and irrevocable settlement. It is further submitted that commitment in the settlement process (on $T+3$ ) would not change the legal position as regards liquidation. This does not mean that all legal consequences on "commitment" would be disregarded. In the absence of any specific legal provisions to the contrary, the "commitment" or the timing of the commitment during the settlement process on $T+3$ does not play any role in determining whether the securities form part of the estate of

\footnotetext{
Letsitele Stores (Pty) Ltd v Roets 19582 SA $224(\mathrm{~T})$.

See s 68 of the Banks Act 94 of 1990 (hereinafter "the Banks Act").

See s $91 \mathrm{~A}(4)(c)$ of the 1973 Companies Act and s 53(4) of the 2008 Companies Act. Ibid.
} 
a client ${ }^{55}$ upon insolvency. This is so because transfer of ownership in the securities is only completed on CSD Participant level on T+5 upon DvP in terms of the Companies Act. Stated differently, even though a contractual obligation has arisen upon "commitment", the contract is still uncompleted in the sense that Simultaneous Final and Irrevocable Delivery-versus-Payment (SFIDvP) only occurs on $\mathrm{T}+5{ }^{56}$

Uncompleted transactions on an exchange are governed by section $35 \mathrm{~A}$ of the Insolvency Act in the event of the liquidation of a participant's estate on the ground that it is unable to pay its debts. Section $35 \mathrm{~A}(1)$ of the Insolvency Act provides that where a market participant ${ }^{57}$ is sequestrated while there are undischarged obligations in respect of any transaction to which the rules of an exchange apply, the exchange to which or the other market participant to whom obligations are owed is entitled to terminate all such transactions in accordance with the rules of the exchange and the trustee will be bound by the termination. The definition of the term "exchange" would include a central securities depository (CSD). Any claim that is instituted resulting from the termination may not exceed the amount due upon termination in terms of the rules of the exchange. ${ }^{58}$ The liquidator will be bound by the rules and practices of the exchange that provide for netting of a market participant's position or for set-off in respect of transactions concluded by the market participant or which provide for the opening of closing of a market participant's position, in respect of every transaction or contract concluded by the market participant prior to the sequestration of his estate but which was to be settled on a date after sequestration or which was overdue on the date of sequestration. ${ }^{59}$ Where there is a disposition of property in accordance with the rules of the exchange, the liquidator cannot institute proceedings to have the transactions set aside as dispositions in terms of the Insolvency Act. ${ }^{60}$

\section{The Securities Services Act, Rules, Directives and Finality}

The SSA is silent on the necessity for Rules on finality of settlement in the event of liquidation, curatorship or business rescue. This is in contrast to section 5 of the National Payment System Act ${ }^{61}$ which spells out clearly when finality of settlements would occur. The only mention of winding-up is in relation to the winding-up, judicial management or appointment of a

55 A "client" is defined in S 1 of the SSA as any person who uses the services of an authorised user or a participant, as the case may be. An "authorised user" refers to a person authorised by an exchange in terms of the exchange rules to perform such securities services as the exchange rules may permit, also commonly referred to as a "broker".

56 This is so in terms of the current s 91A of the Companies Act. S 53 of the 2008 Companies Act.

57 S $35 \mathrm{~A}(1)$ defines "market participant" as an authorised user, a participant, a client or a settling party as defined in $\mathrm{S} 1$ of the SSA, or any other party to a transaction.

58 S $35 \mathrm{~A}(3)$.

59 S $35 \mathrm{~A}(4)$.

60 See ss 26, 2930 and 35B(3) of the Insolvency Act.

6178 of 1998 (hereinafter "the NPS Act"). 
curator to "regulated persons" in sections 107-109 of the SSA, that is, selfregulatory organisations such as the CSD.

Section $35 \mathrm{~A}$ of the Insolvency Act states that a liquidator, judicial manager or curator would be bound by the rules of an exchange or CSD, but there is no clarity on the way in which the curator or liquidator is bound. For example, from which moment will the curator or liquidator be bound and for how long? This is different from the position in section 8 of the NPS Act that clearly states the extent, time and consequences to which the curator or liquidator will be bound. ${ }^{62}$ The CSD may only make rules on matters indicated in section 39(2) or on additional matters with the approval of the Registrar. Even if the Registrar gives such approval, the Rules will nevertheless only be applicable to the CSD, CSD Participants, issuers and clients in terms of section 39(4) of the SSA. "Client" is defined as any person who uses the services of an authorised user or a participant. "63 "Issuer" means an issuer of securities and, in Chapter IV, includes an issuer of money market instruments. ${ }^{64}$

It is unclear whether the provisions of section 35A of the Insolvency Act would make the CSD Rules applicable to persons other than those mentioned in section 39(4) of the Securities Services Act. It may therefore be necessary to amend this section to make the Rules binding on a liquidator, curator or judicial manager as the case may be.

Like the SSA, the Rules are silent on the impact of insolvency on finality of settlement and achievement of DvP, except for certain practical arrangements that were made. The SSA mandates segregation of accounts and also states that no CSD or participant may become the owner of securities merely because such securities have been deposited with it or registered in its name. ${ }^{65}$ If a CSD or participant does not become the owner and keeps its securities separate from those of its clients, such securities should not fall within the insolvent estate and should not be subject to the power of the liquidator. In this sense, ownership as described in the SSA as well as segregation of accounts can play a protective role against the provisions of the Insolvency Act. The Rules on segregation of accounts and transfer of accounts cater for the following:

- They ensure that securities are not placed in a fungible pool (i.e., are ringfenced);

- transfer of securities of the failed participant to another participant's account has to take place;

- a trust account has to be created; and

- mandates of clients of failed participants have to be amended within 30 days and consequences of failure to advise of new instructions spelt out.

\footnotetext{
See $s$ of the NPS Act.

S1 of the SSA.

Ibid.

65 See s 40(2)(a) of the SSA.
} 
It would be in the interest of all the stakeholders that settlement finality be clarified, that is, from which moment can the transaction not be unwound? Section 35A refers to Rules which are needed and which will be binding on the liquidator, judicial manager (business rescue practitioner) or curator, as the case may be. It is submitted that these Rules may provide that the instructions and book-entries shall be legally enforceable and binding even in the event of curatorship, business rescue or insolvency proceedings against a participant of the system, provided that the instructions were entered into the system before the commencement (granting of a court order or passing of a resolution on a voluntary winding-up) of the insolvency proceedings. Furthermore, it is submitted that the moment of entry of an instruction into the system should be as early as possible and not, for example, by reference to the moment of irrevocability or matching of the settlement instruction in the system. This is because of the retroactive nature of the commencement of insolvency proceedings as provided for in section 348 of the Companies Act.

For the above to be achievable, an amendment to section 39(4) of the SSA is necessary that would provide that a curator or liquidator or business rescue practitioner will be bound to the Rules, and an amendment should provide that the CSD must have Rules on finality of settlement. The latter will strengthen the protection given in section 35A of the Insolvency Act.

It is important to consider the difference between the primary legislation and secondary legislation because if the Rules (secondary legislation) do not have a good, solid legal foundation in primary legislation, a conflicting provision in primary legislation may take precedence over the Rules, or such Rules may fall foul of being ultra vires. For this reason it is important that amendments be made to the SSA, which will give the foundation and authority for the Rules that are needed to make sections 35A more effective.

In terms of the Directive on Special Circumstances for the Reversal of Commitments (Equities) ${ }^{66}$ an order pertaining to a sequestration event of a client or a participant is included as a special circumstance under which a committed settlement may, after $12 \mathrm{~h} 00$ on $\mathrm{T}+3$, be reversed. Winding-up the appointment of a curator, trustee or liquidator in respect of the estate of a Client of a participant, and the granting of a judicial management order or appointment of a judicial manager in respect of the Client of a participant, is deemed to be included as a "sequestration event". ${ }^{67}$ Where the estate of a Client of a participant is placed under business rescue in terms of the 2008 Companies Act it should similarly be deemed to be a sequestration event. The reversal of commitments under these circumstances would not apply in the event of insolvency, judicial management, business rescue or appointment of a curator to a CSD Participant as these instances are not included under the definition of "sequestration event".

$\begin{array}{ll}66 & \text { CSB. } \\ 67 & \text { See par } 2 \text { above. }\end{array}$ 


\section{Effect of judicial management of participant}

The purpose of placing a company under judicial management in terms of the 1973 Companies Act would be to allow a company that has become unable to pay its debts or a company that has been prevented from becoming a successful concern ${ }^{68}$ with an opportunity to become able to pay its debts by replacing its current board of directors with a judicial manager. The purpose of judicial management is to enable a company suffering a temporary setback due to mismanagement or other special circumstances to once again become a successful concern. A judicial management order usually provides a moratorium with regard to the company's debts. ${ }^{69}$ If a company is unable to pay its debts or meet its commitments, this means that the protection of the interests of the creditors enjoys more attention than in the case of ordinary companies, and certain principles of the law of insolvency are applied.

Judicial management in the Banks Act has been substituted for curatorship and hence judicial management would only apply to Non-Bank Participants. ${ }^{70}$ Upon appointment of a judicial manager in respect of a NonBank Participant, the management of the company is divested from the existing management and placed under the control of the judicial manager. Judicial management has been criticized in that it does not really address the problems of the company effectively.

The 2008 Companies Act replaces the judicial management system for dealing with failing companies with a business rescue system. A detailed discussion of the judicial management system as provided for in the 1973 Companies Act falls outside the ambit of this article as a result of the system having been repealed by the 2008 Companies Act.

\section{Business rescue}

In accordance with the reform objectives and specific goals agreed on during the corporate law reform process that resulted in the promulgation of the 2008 Companies Act the existing regime of judicial administration of failing companies is repealed and replaced with a business rescue regime. The business rescue regime is largely self-administered by the company, under independent supervision within constraints set out in the Act and subject to court intervention at any time on application by any of the stakeholders. ${ }^{71}$ The memorandum provides that the new system of business rescue recognizes the interests of shareholders, creditors and employees, and provides for their respective participation in the development and approval of a business rescue plan. ${ }^{72}$

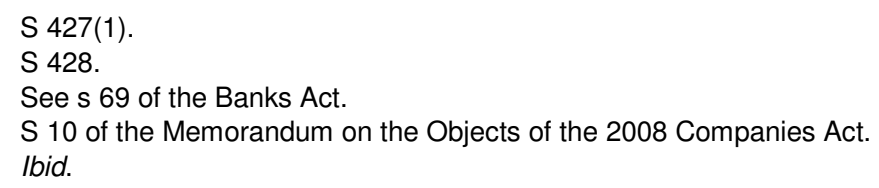


"Business rescue",73 is defined as proceedings to facilitate the rehabilitation of a company that is financially distressed by providing for:

(i) The temporary supervision of the company, and of the management of its affairs, business and property;

(ii) a temporary moratorium on the rights of claimants against the company or in respect of property in its possession; and

(iii) the development and implementation, if approved, of a plan to rescue the company by restructuring its affairs, business, property, debt and other liabilities, and equity in a manner that maximises the likelihood of the company continuing in existence on a solvent basis or, if it is not possible for the company to so continue in existence, results in a better return for the company's creditors or shareholders than would result from the immediate liquidation of the company.

Business rescue proceedings can be commenced in two ways: firstly, the company can resolve to commence business rescue proceedings, ${ }^{74}$ and secondly, a court may grant an order to commence business rescue proceedings. ${ }^{75}$

\section{Company resolution to commence business rescue}

A company is deemed to be financially distressed if it appears to be reasonably unlikely that the company will be able to pay all of its debts as they fall due and payable within the immediately ensuing six months or it appears to be reasonably likely that the company will become insolvent within the immediately ensuing six months. ${ }^{76}$ The board of a company may resolve that the company voluntarily begin business rescue proceedings and place the company under supervision, if the board has reasonable grounds to believe that the company is financially distressed and there appears to be a reasonable prospect of rescuing the company. ${ }^{77}$

A company may not resolve to commence business rescue proceedings where liquidation proceedings have been initiated by or against the company. ${ }^{8}$ The resolution by the company will have no force or effect until it has been filed. ${ }^{79}$ Within five business days after a company has adopted and filed a resolution the company must publish and deliver a notice of the resolution, and its effective date to every affected person. ${ }^{80}$ The notice must include a sworn statement of the facts relevant to the grounds on which the board resolution was founded. ${ }^{81}$ "Affected person" includes a shareholder or

${ }^{73}$ S 128(1)(b) of Chapter 6 Business Rescue and Compromise with Creditors of the 2008 Companies Act.

$74 \mathrm{~S} 129$ of the 2008 Companies Act.

$75 \mathrm{~S} 131$.

$76 \mathrm{~S} 128(1)(\mathrm{f})$.

S 129.

$78 \mathrm{~S} 129(2)$

79 S 129(2)(b).

$80 \mathrm{~S}$ 129(3).

$81 \mathrm{~S}$ 129(3)(a). 
creditor of the company, any registered trade union representing employees and individual employees who are not represented. ${ }^{82}$ The company must also appoint a business rescue practitioner. ${ }^{83}$ Once a company has adopted a resolution to commence business rescue proceedings it may not adopt a resolution to begin liquidation proceedings, unless the resolution relating to the business rescue has lapsed or the business rescue proceedings have ended $^{84}$.

Where the board of a company has reasonable grounds to believe that the company is financially distressed and the board has not adopted a resolution to commence business rescue proceedings, the board must deliver a written notice to each affected person of its reasons for not adopting a resolution. ${ }^{85}$

\section{Court order to begin business rescue proceedings}

An affected person may apply to a court at any time for an order placing the company under supervision and commencing business rescue proceedings. ${ }^{86}$ The court may grant the order if it is satisfied that the company is financially distressed or the company has failed to pay over any amount in terms of an obligation under or in terms of a public regulation, or contract, with respect to employment-related matters or it is otherwise just and equitable to do so for financial reasons and there is a reasonable prospect for rescuing the company.

\section{Effect of business rescue proceedings}

During business rescue proceedings no legal proceeding, including enforcement action against the company, or in relation to any property belonging to the company, or lawfully in its possession, may be commenced or proceeded with in any forum, except

(i) with the written consent of the business rescue practitioner, or

(ii) with the leave of the court and in accordance with any terms the court considers suitable, ${ }^{87}$ or

(iii) as a set-off against any claim made by the company in any legal proceedings ${ }^{88}$.

These rules apply irrespective of whether the proceedings commenced before or after the business rescue proceedings began.

\footnotetext{
$S$ 128(1)(a).

S 129(3)(b)

${ }^{84} \mathrm{~S}$ 129(6).

$85 \mathrm{~S}$ 129(7)

$86 \mathrm{~S} 131$.

87 S133(1).

$88 \mathrm{~S} 133(1)(\mathrm{c})$
} 
During business rescue proceedings a guarantee or surety by a company in favour of any other person may not be enforced by any person against the company, except with leave of the court and in accordance with any terms the court considers just and equitable in the circumstances. ${ }^{89}$ If any right to commence proceedings or otherwise to assert a claim against a company is subject to a time limit, the measurement of that time must be suspended during the company's business rescue proceedings. ${ }^{90}$

During a company's business rescue proceedings the company may dispose, or agree to dispose, of property only in the ordinary course of its business in a bona fide transaction at arm's length for fair value approved in advance and in writing by the practitioner or in a transaction contemplated within, and undertaken as part of the implementation of a business rescue plan that has been approved. ${ }^{91}$

Despite any provision of an agreement to the contrary, no person may exercise any right in respect of any property in the lawful possession of the company, irrespective of whether the property is owned by the company, except to the extent that the practitioner consents in writing.

If, during a company's business rescue proceedings, the company wishes to dispose of any property over which another person has any security or title interest, the company must obtain the prior consent of that other person, unless the proceeds of the disposal would be sufficient to discharge the indebtedness protected by that person's security or title interest fully, and promptly pay to that other person the sale proceeds attributable to that property up to the amount of the company's indebtedness to that other person, or provide security for the amount of those proceeds to the reasonable satisfaction of that other person. ${ }^{93}$

Subject to sections $35 \mathrm{~A}$ and $35 \mathrm{~B}$ of the Insolvency Act, despite any provision of an agreement to the contrary during business rescue proceedings, the practitioner may cancel or suspend entirely, partially or conditionally any provision of an agreement to which the company is a party at the commencement of the business rescue period, other than an agreement of employment. Any party to an agreement that has been suspended or cancelled; or any provision which has been suspended or cancelled may assert a claim against the company only for damages. The business rescue practitioner would thus not have the choice to decide whether to cancel or suspend the agreement.

The discussion in paragraph 21 above on section 35A would be applicable mutatis mutandis to business rescue once this section has been amended to remove any references to judicial management and to replace such with business rescue.

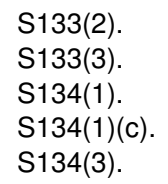




\section{Effect of curatorship of participant}

A bank may be placed under curatorship in terms of section 69 of the Banks Act, 1990. Prior to making any announcement regarding the placing of a bank under curatorship, the Bank Supervision Department of the South African Reserve Bank (SARB) and the designated curator must take cognisance of the risks that could be introduced into the National Payment System (NPS). Section 69 sets out the considerations to be taken into account before a curator may be appointed. If, in the opinion of the Registrar of Bank, any bank will be unable to repay, when legally obliged to do so, deposits made with it, or will probably be unable to meet any other of its obligations, the Minister of Finance may, if he deems it desirable in the public interest, with the written consent of the Chief Executive Officer or the chairman of the board of directors of that bank, appoint a curator to the bank. On appointment of a curator, any person vested with the management of the affairs of the bank is divested of such powers and management of the bank concerned vests in the curator, subject to the supervision of the Registrar. The curator is obliged to recover and take possession of all the assets of the bank. ${ }^{94}$ These assets include all cash deposited with the bank and would include any deposits made with the bank after the appointment of the curator. The curator has the right to decide whether or not to abide by any contract entered into by the defaulting bank. ${ }^{95}$

The appointment of a curator does not necessarily mean that the day-today business of the bank would not continue. In other words, the mere appointment of a curator does not necessarily result in a failure of that bank being declared or the Strate licence of the CSD Participant being terminated.

In terms of section $69(6 \mathrm{~B})$, notwithstanding anything to the contrary contained in the Banks Act, sections 35A, 35B and 46 of the Insolvency Act, shall mutatis mutandis apply to the curator of any bank under curatorship and to such a bank as if the curator were a trustee of an insolvent estate and the bank were an insolvent or a sequestrated estate as contemplated in those sections. For the purpose of this discussion, therefore, the position as set out in paragraph 21 above on uncompleted contracts and section 35A would apply mutatis mutandis in the case of appointment of a curator to a CSD Participant.

\section{SELECTED LEGISLATION OF FOREIGN JURIS- DICTIONS}

\section{General}

The question arises how other jurisdictions deal with finality and irrevocability of settlement. A snapshot of the findings of selected foreign jurisdictions is provided below:

${ }^{94} \mathrm{~S} 69(2 \mathrm{~A})$ of the Banks Act.

95 See $s$ 692(A)-(G) on all the functions of the curator. 


\section{UNIDROIT (Geneva Securities Convention) ${ }^{96}$}

UNIDROIT is the International Institute for the Unification of Private Law. UNIDROIT undertook a project on substantive rules regarding intermediated securities (Study LXXVIII) in order to create an international instrument for improving the legal framework for securities holding, transfer and collateralisation. On a regional level the Directives on Settlement Finality and Financial Collateral set out a fragmented legal framework for securities holding and disposition in the European Union, with special emphasis on collateral transactions. Recently the diplomatic Conference of UNIDROIT held a final session in Geneva from 5 to 9 October 2009 to adopt a Convention on Substantive Rules for Intermediated Securities. ${ }^{97}$ On 9 October the Conference adopted the Convention and gave it the new name UNIDROIT Convention on Substantive Rules for Intermediated Securities (the "Geneva Securities Convention"). On the same day the Final Act was signed by 37 States, including South Africa and the European Community, and the Convention was adopted by one state, namely Bangladesh. The Geneva Securities Convention sets out principles or legal rules that member States should incorporate into domestic legislation. In terms of Article 40 the Convention it is open for signature by States at the UNIDROIT Headquarters in Rome from 9 October 2009 until it comes into force. ${ }^{98}$ The Convention enters into force on the first day of the month following the expiration of six months after the date of deposit of the third instrument of ratification, acceptance, approval or accession between the States that have deposited such instruments.

The Convention is subject to ratification, acceptance or approval by States that have signed it and any State that does not sign the Convention may accede to it at any time. Ratification, acceptance, approval or accession is effected by the deposit of a formal instrument to that effect with the UNIDROIT depository.

With regards to finality and irrevocability of settlement, the Geneva Securities Convention provides that, subject to Article 16, intermediated securities and security interests are acquired by an account holder by the credit of securities or security interests to that account holder's securities account. ${ }^{101}$ No further step is necessary or may be required by the non-

96 South Africa, a member, was represented by Dr Maria Vermaas of Strate at the First Session of the Diplomatic Conference to Adopt a Convention on Substantive Rules regarding Intermediated Securities in Geneva from 1-12 September 2008. The purpose of the session was to consider the draft Convention. The final Convention can be accessed from http://www.unidroit.org (accessed 2009-11-02) (hereinafter "Geneva Securities Convention").

97 Intermediated securities can be defined as "securities credited to a securities account of rights or interests in securities resulting from the credit of securities to a securities account".

98 Article 40(1).

99 See Article 42(1).

100 Article 40(2)-(4).

101 See Article 11. Article 16 provides that the non-Convention law and to the extent permitted by the non-Convention law, the account agreement or the uniform rules of a securities settlement system determine whether and in what circumstances a debit credit, designating entry or removal of a designating entry is invalid, liable to be reversed or may be subject to a 
Convention law or any other rule of law applicable in an insolvency proceeding to render the acquisition of intermediated securities effective against third parties. ${ }^{102}$ Rights and interests that have become effective against third parties are effective against the insolvency administrator and creditors in any insolvency proceeding. ${ }^{103}$ However, this provision does not affect the application of any substantive or procedural rule of law applicable by virtue of an insolvency proceeding, such as any rule relating to the rank-ing of categories of claims, ${ }^{104}$ avoidance of a transaction as a preference or a transfer in fraud of creditors ${ }^{105}$ or any rules of procedure relating to the enforcement of rights which are under the control or supervision of an insolvency administrator. ${ }^{106}$ As indicated earlier, dispositions of securities fall outside the ambit of this article and will be dealt in a separate article.

Of particular importance for the issue of settlement finality is Article 16 of the Geneva Securities Convention which provides that the non-Convention law, and to the extent permitted by the non-Convention law, the account agreement or the uniform rules of a securities settlement system determine whether, and in what circumstances, a debit, credit, designating entry or removal of a designating entry is invalid. This issue is liable to be reversed or may be subject to a condition, as well as the consequences thereof.

Article 27 which deals with the insolvency of a system operator or participant, provides:

"To the extent permitted by the law governing the relevant system, the following provisions shall have effect notwithstanding the commencement of an insolvency proceeding in relation to the operator of that system or any participant in that system and notwithstanding any invalidation, reversal or revocation that would otherwise occur under any rule applicable in an insolvency proceeding:

(a) any provision of the uniform rules of a securities settlement system or of a securities clearing system in so far as that provision precludes the revocation of any instruction given by the participant in the system for making a disposition of intermediated securities, or for making a payment relating to an acquisition or disposition of intermediated securities, after the time at which that instruction is treated under the rules of the system as having been entered irrevocably into the system;

(b) any provision of the uniform rules of a securities settlement system in so far as that provision precludes the invalidation or reversal of a debit or

condition and the consequences thereof. Article 16 is subject to Article 18 , which deals with acquisition by an innocent person.

102 Article 11(2).

${ }^{103}$ Article 14(1). See also Article 14(4). Article 11 deals with acquisition by credit of the securities account of the account holder and Article 12 deals with acquisition of securities or security interests by other means, namely by means of an agreement in favour of the beneficiary or one of the conditions specified in Article 12(3) applies and the State has made a declaration in relation to that condition in terms of par 5 of Article 12. These conditions are that the person to whom the interest is granted is the relevant intermediary, a designating entry in favour of that person has been made and a control agreement in favour of that person applies. The Convention does not preclude other methods of acquiring securities or security interests than those provided for in Articles 11 and 12. See in this regard Article 13.

104 Article 14(2)(a).

105 Article 14(2)(b).

106 Article 14(2)(c). 
credit of securities to, or a designating entry or removal of a designating entry in, a securities account that forms part of the system after the time at which that debit, credit, designating entry or removal of a designating entry is treated under the rules of the system as not liable to be reversed." (own emphasis)

It is evident from the above that in order to "override" the normal insolvency law relating to commencement of insolvency proceedings and those provisions which make it possible to invalidate, reverse or revoke entries, the uniform rules of the securities settlement system, that is, the rules of the CSD, would have to provide for the time at which that instruction is treated under the rules of the system as having been entered irrevocably into the system, as well as the time when the entry of a credit, debit or designating entry can no longer be reversed. In other words, legislative amendments are necessary to ensure that settlement system rules shall have effect notwithstanding the commencement of insolvency proceedings over the system or a participant in the system, and that this would have to override "normal" insolvency law principles. Furthermore, specific CSD Rules are needed to ensure that no invalidation or reversal or revocation of a debit or credit entry is possible after the entry is treated as final under the rules of the system. A provision is also necessary to preclude the revocation of any instruction given for making a disposition or payment after the time which the instruction is treated as having been entered irrevocably into the system under the rules of the system. It would be necessary to clarify the "moment" of such finality and irrevocability of an entry, in addition to ensuring the validity of the additional Rules, since neither the SSA nor the CSD Rules provide for finality of settlement. The provisions in the Geneva Securities Convention assume that such "moment" is clear in domestic law. The SSA and the CSD Rules will have to be amended to incorporate the provisions of the Geneva Securities Convention on finality and irrevocability.

To date Bangladesh is the only State which signed the Convention, and the latest status report on the Convention indicates no ratifications to date. ${ }^{108}$ It appears that even though South Africa has adopted the Final Act, it still has to ratify the Convention. Article 42 of the Geneva Securities Convention states that for each State that ratifies, accepts, approves or accedes to this Convention after the deposit of the third instrument of ratification, acceptance, approval or accession, the Convention enters into force in relation to that State on the first day of the month following the expiration of six months after the date of the deposit of its instrument of ratification, acceptance, approval or acceptance. As a member and signatory to the Final Act, South Africa's current legal framework relating to the financial market will have to be aligned to the provisions of the Convention. Should a Participant Failure occur in the absence of the amended legislation, it has been agreed to use the Participant Failure Manual, drafted by Strate in conjunction with the JSE Limited. It has to be noted, however, that the Manual does not have legal power and that enforcement thereof would not be supported by legislation. The Legal Division of Strate has conducted an examination to determine the extent to which the legislation would have to

\footnotetext{
107 Article 27.

108 See http://www.unidroit.org (accessed 2009-12-07).
} 
be amended in alignment with the Convention, and have made certain recommendations to the Financial Services Board and the National Treasury. It is encouraging to learn that the Financial Services Board and the National Treasury have since decided that the Securities Services Act will be scheduled for, and included on, the Parliamentary programme for amendments in $2010{ }^{109}$

\section{European Union}

Another approach could be found in the European Union Parliament Directive on Settlement Finality. The position in the United Kingdom is used to illustrate the enactment of this Directive in the European Union. The position in Norway is used to illustrate another perspective of a member state of the European Union. Canada has been selected to provide a "nonEuropean" approach.

The European Parliament Directive 98/26 on Settlement and Finality of Payment and Settlement systems has set the stage for legislation giving effect to settlement finality notwithstanding the commencement of insolvency proceedings in the European Union. ${ }^{110}$

The Settlement Finality Directive provides that transfer orders and netting are legally enforceable and binding on third parties, even in the event of insolvency proceedings against a participant, provided that transfer orders were entered into a system before the moment of opening of such insolvency proceedings. Where, exceptionally, transfer orders are entered into a system after the opening of such insolvency proceedings and are carried out on the day of opening of such proceedings, they are binding on third parties only if the settlement agent, the central counterparty or the clearing house can prove that they were not aware, nor should have been aware, of the opening of such proceedings. ${ }^{111}$ The moment of entry of a transfer order into a system is defined by the rules of that system. ${ }^{1}$

Article 3(2) provides that no law, regulation, rule or practice on the setting aside of contracts and transactions concluded before the moment of opening of insolvency proceedings shall lead to the unwinding of a netting. Opening of insolvency proceedings is defined as the moment when the relevant judicial or administrative authority handed down its judgment. ${ }^{113}$

The Settlement Finality Directive also provides that insolvency proceedings may not have retroactive effect on the rights and obligations of a participant arising from, or in connection with, its participation in a system earlier than the moment of opening of the insolvency proceedings. ${ }^{114}$ In the event of insolvency proceedings being opened against a participant in a system, the rights and obligations in connection with that participation are

109 Strate Regulatory and Supervisory Report 20099.

110 Hereinafter "the Settlement Finality Directive".

111 Article 3(1).

112 Article 3(3).

113 Article 6(1).

114 Article 7. 
determined by the law governing the system in question. ${ }^{115}$ Where collateral is provided in the form of securities (including rights in securities) the rights of the relevant participants and of the central banks of the Member States and of the European Central Bank are determined by legislation of the Member State where their rights are registered. ${ }^{11}$

In summary, the common rules found in the Settlement Finality Directive, provide that:

- Transfer orders and netting must be legally enforceable; ${ }^{117}$

- transfer orders may not be revoked once they have been entered into the system;

- the insolvency law applicable is the law of the Member State involved; and

- collateral security provided to a system by a participant may not be affected by the opening of insolvency proceedings against that participant.

\section{United Kingdom}

The relevant provisions under English insolvency law are contained principally in the Insolvency Act. ${ }^{118}$ However, certain provisions of the 1986 Insolvency Act which might affect the transfer of good title in CREST ${ }^{119}$ securities are disapplied in certain material respects by Part VII of the 1989 Companies Act and the Financial Markets and Insolvency (Settlement Finality) Regulations 1996, and by the Settlement Finality Directive 1999.

CREST Rule 13 covers the transfer of UK and Irish securities, the making of payments in central bank money, as well as certain "default arrangements" to limit systemic and other types of risk which might arise in the event of a participant appearing to be unable, or likely to become unable, to meet its obligations in respect of a transfer order.

The UK Settlement Finality Regulations implement the EU Settlement Finality Directive of 19 May 1998 on settlement finality in payment and securities settlement systems. The protection provided by the UK Settlement Finality Regulations is given to securities and/or payment settlement systems which have been or were designated in the UK or Ireland. Chapter VII of the 1986 Insolvency Act makes provision for default rules. Section 14 of the Settlement Finality Regulations provides that the proceedings of designated systems take precedence over insolvency proceedings. ${ }^{120}$

${ }^{115}$ Article 8.

116 Article 9(1).

117 Article 3.

118 See the First Group of Parts dealing with winding-up of companies, Parts I-VII, in the Insolvency Act, 1986.

119 The CREST system is the world's largest settlement system for domestic and international securities transactions, covering bonds, equities and investment funds. CREST is the CSD for the United Kingdom (UK) market and for Irish equities, owned and operated by CRESTCo. CRESTCo is part of the Euroclear Group. For more detail see http://www.euroclear.com (accessed 2009-01-26).

$120 \mathrm{~S} 14$ provides that none of the following shall be regarded as to any extent invalid at law on the ground of inconsistency with the law relating to the distribution of the assets of a person 
Furthermore, the power to rescind contracts and reclaim property in terms of the 1986 Insolvency Act is disapplied.

Insolvency law is overridden, provided that the transfer order is carried out on the same day as the "insolvency event" and the settlement agent, central counterparty or the clearing house can show that it did not have notice of that event at the time of settlement of the transfer order. Furthermore, the power of a relevant office-holder and the court may not be exercised to interfere with the settlement in accordance with the rules of a designated system, any action taken under its default arrangements, any action to realise collateral security pursuant to its default arrangements or any action to realise collateral security in connection with the functions of a central bank. ${ }^{121}$

CREST Rule 13 forms part of the CREST Requirements and has been drafted to satisfy the requirements of the UK Settlement Finality Regulations. CREST Rule 13 covers the transfer of UK and Irish securities, the making of payments in central bank money, as well as certain "default arrangements" to limit systemic and other types of risk which might arise in the event of a participant appearing to be unable, or likely to become unable, to meet its obligations in respect of a transfer order. CREST Rule 13 provides reassurance to CREST members and settlement banks that a settled transaction (either a transfer of title to securities or the creation or settlement of a settlement bank payment obligation) is not at risk of being unwound (or otherwise interfered with) if the relevant company becomes insolvent.

The Settlement Finality Directive determines that the rules of the designated system must specify:

- The moment at which a transfer order enters the system; and

- the moment at which the transfer order becomes incapable of revocation by act of a participant or third party (which is understood to include a liquidator or other insolvency office-holder).

The Settlement Finality Directive makes it clear that the moment at which a transfer order enters a system (a), and the moment of its irrevocability (b) are logically separate matters.

Under CREST Rule 13, (a) above, is defined as occurring at the moment that the relevant settlement instruction is received by the CREST Applications Host; ${ }^{122}$ and (b) above, arises at the point at which a transaction

on bankruptcy, winding up, sequestration or under a protected trust deed, or in the administration of an insolvent estate:

- A transfer order;

- the default arrangements of a designated system;

- the rules of a designated system as to the settlement of transfer orders not dealt with under its default arrangements;

- a contract for the purpose of realising collateral security in connection with participation in a designated system otherwise than pursuant to its default arrangements; or

- a contract for the purpose of realising collateral security in connection with the functions of a central bank.

121 S 14(2).

122 Rule 13 par 2.1. 
is no longer capable of being amended or deleted by a single party to the transaction.

This allows flexibility for the parties to amend or cancel or delete a transaction by consent (using CREST-matched deletion functionality) but otherwise means that a defaulting party cannot unilaterally revoke the transaction after this time.

\section{Norway}

VPS is the CSD of Norway. ${ }^{124}$ The Norwegian Securities Depository Act ${ }^{125}$ came into force on 1 January 2003 and replaced the 1985 Act which regulated the CSD. With the Norwegian Securities Depository Act, VPS's legal monopoly as a securities depository was abolished and a licence from the Ministry of Finance is required of any entity wishing to operate as a securities depository. The point of departure is that financial instruments are registered in the securities depository in the investor's name. In some cases the custodian bank is allowed to register, which means that the name of the actual owner does not appear in the securities depository. The custodian bank must be approved by Kredittilsynet (Financial Supervisory Authority of Norway).

The Payments Systems Act of 2000 assigns Norges Bank with the responsibility of authorising and supervising interbank systems in Norway. According to the Act relating to Payment Systems, the securities settlement system must be approved by the Kredittilsynet in order to be covered by the legal protection rules for clearing and settlement agreements in terms of the Act. VPS has had such approval since 6 June 2001.

Section 4(2) of the Act relating to Payment Systems provides that agreements on clearing and settlement may be applicable subject to their content even if the insolvency proceedings against a participant in the system are opened when the transfer order is entered into the system before the opening of insolvency proceedings. The moment when the order shall be considered received on the system shall be agreed upon between the participants in the system. The same applies to the moment when the right to revoke the order no longer applies. Kredittilsynet may lay down rules for with respect to the moment when the order is considered received in the securities settlement system.

If the order is entered into the system after the opening of insolvency proceedings commence, the provision also applies if the clearing house, central counterparty or settlement bank can prove that they were not aware,

123 Rule 13 par 3.

124 VPS ASA is a Norwegian public-limited company, which is authorised to register rights to financial instruments with the legal effects laid down in the Act relating to the Registration of Financial Instruments. From 1985 until 2002, VPS was a self-owned institution established under the provisions of the 1985 Act relating to the Norwegian Central Securities Depository. The old legislation has been replaced by an Act relating to the Registration of Financial Instruments, which entered into force on 1 January 2003. See the VPS website http://www.vps.com (accessed 2009-01-26).

12564 of 2002. 
nor should have been aware, of the opening of solvency proceedings after the moment of settlement.

\section{Canada}

The Canadian Depository for Securities Limited (CDS) has created an enhanced securities clearing and settlement system (CDSX) which virtually settles all securities in Canada. CDS is recognised as a clearing agency by the Ontario Securities Commission pursuant to the Ontario Securities Act ${ }^{126}$ and has been authorised by the Autorite des marches financiers to conduct clearing activities in Québec. ${ }^{127}$ In addition, CDS is deemed to be the clearing house for CSDX, a clearing and settlement system designated by the Bank of Canada pursuant to section 4 of the Payment Clearing and Settlement Act. ${ }^{12}$

This Act ${ }^{129}$ provides that, notwithstanding any law:

(a) The settlement rules of a designated clearing and settlement system are valid and binding on the clearing house participants, a central counterparty and the Bank of Canada;

(b) where the settlement rules provide so, the settlement of a payment through an entry to or a payment out of an account of a participant, clearing house or central counterparty or the Bank of Canada is final and irrevocable and such entry or payment cannot be reversed or set aside.

Furthermore, the Act ${ }^{130}$ provides that an entry to or payment out of the account of a participant, clearing house or central counterparty at the Bank of Canada cannot be subject to any provision or order that operates as a stay of that activity.

\section{Summary}

The following findings are evident from a comparative analysis of the legislations of these countries:

- Each of the countries examined has a special dispensation to ensure the finality and irrevocability of settlement despite the commencing of insolvency proceedings;

- most countries have enacted separate legislation. It is interesting to note that the protection does not always appear in the insolvency laws themselves but in other forms of legislation, most particularly Payment and Settlement Systems legislation. The reason for this is most probably the fact that some countries have either a single regulator (such as in the UK and Canada) or the central bank plays a significant role in the regulation of securities (eg, Australia and Canada);

\footnotetext{
${ }^{126}$ See s 21.1 of the Act.

127 See ss $169-170$ of the Québec Securities Act.

1281996.

${ }^{129}$ S 8(1) of the Payment Clearing and Settlement Act, 1996.

130 See s 8(2).
} 
- most countries use the concept of designation of clearing and settlement systems and finality of settlement. Enforceability of settlement agreements and the binding nature on the liquidator are express consequences of such designation;

- in some instances default rules are provided for (UK) and all countries have carve-outs (exceptions); and

- security interests are protected.

\section{LEGISLATIVE AMENDMENTS}

This article raised some uncertainties regarding the finality and irrevocability of settlement of securities. The provisions of the Unidroit Convention emphasise the need for settlement finality rules and indicate which rules would be necessary to ensure that no reversal or invalidation should be able to occur after the settlement entry is treated as "final" and "irrevocable". The approaches followed by some foreign jurisdictions were used to highlight possible ways of overcoming the uncertainties and legislative lacunae. It is suggested that the SSA and the CSD Rules would have to be amended. It is submitted that the following specific legislative amendments are necessary:

Firstly, section 39(4) should be amended to make the Rules binding on a curator, business rescue practitioner or liquidator or similar official (to cater for business rescue once the Companies Bill is enacted). Such an amendment will provide legal certainty that the CSD rules are binding on such officials in addition to the binding nature of section $35 \mathrm{~A}$ of the Insolvency Act.

Secondly, similar to the examples in the selected foreign jurisdictions, there should be a special dispensation to cater for finality of settlement in the form of specific carve-outs similar to other jurisdictions.

Thirdly, the SSA has to refer to Rules on finality of settlement of securities to strengthen the framework. In this regard, section 39(2) should be amended to include wording to that effect.

In the fourth instance it is submitted that, similar to the Unidroit Convention and European Settlement Finality Directive and its implementation in domestic legislation in European countries, the CSD Rules could be amended to provide that the instructions and book-entries shall be legally enforceable and binding even in the event of curatorship or insolvency proceedings against a participant of the system or insolvency proceedings against the CSD, provided that the instructions were entered into the system before the commencement (granting of a court order or passing of a resolution on a voluntary winding-up) of the insolvency proceedings. The moment of entry of an instruction into the system should be as early as possible and not, for example, by reference to the moment of irrevocability or matching of the settlement instruction in the system. As stated above, this moment should be as early as possible due to the retrospective nature of the commencement of insolvency.

In the fifth instance the level and extent of protection has to be decided upon and stated. It is unclear at which level protection should be given, that 
is, should such protection extend beyond the subregister? If the model is changed to something else than a subregister as the new wording of section 53 seems to suggest, the reasons for clarification become even more necessary.

Finally, it is clear from the comparative analysis that additional protection is given to protect the investor, but this is done in various other ways, such as depositor protection funds or schemes, guarantee funds and insurance. It is therefore recommended that a protection fund be established. This is perhaps something which the National Treasury would wish to revive. It has been on the table in the past, but no significant progress has yet been made.

\section{$7 \quad$ CONCLUSION}

Finality of settlement is the cornerstone of a stable settlement system and financial system stability and it is important that settlement should not be possible to be unwound, even in the event of failure of a participant. It is further important that insolvency protections measures exist in both the payments and securities settlement systems and that the one does not have better protection measures than the other, which could lead to what is referred to as "regulatory arbitrage". Furthermore, it is important that, in drafting the proposed legislation, the correlation between the different pieces of legislation be understood and well aligned.

This article highlighted some of the lacunae in the current framework which could be rectified in order to strengthen the legal framework pertaining to the finality and irrevocability of settlement of securities in the event of failure of a CSD Participant as a result of inability to pay its debts. The article explains some of the approaches followed in the European Union and also uses Canada as an example of a "non-European" approach. Recommendations are made on legislative amendments that are necessary in view of the Unidroit Convention and the uncertainties raised in this article. Policy makers are reminded that it is important that legal clarity exists for the reasons mentioned in the article, even though there may be practical arrangements to overcome some of the legal uncertainties. It is submitted that practical arrangements could go only so far to protect those most vulnerable to a failure of a CSD Participant, namely a client or investor. 